\title{
Vizuální prostředky pro výuku reálií: výsledky analýzy učebnic němčiny ${ }^{1}$
}

\author{
Karolína Pešková \\ Masarykova univerzita, Pedagogická fakulta, Katedra německého jazyka a literatury
}

Redakci zasláno 15. 3. 2012 / Do tisku přijato 23. 5. 2012

\begin{abstract}
Abstrakt: Studie představuje výsledky kvantitativní analýzy učebnic z hlediska vizuálních prostředků pro výuku reálií. Výzkumný vzorek tvořily čtyři učebnice, které jsou určeny pro výuku němčiny jako druhého cizího jazyka na 2. stupni ZŠ. Výsledky poukázaly na společné charakteristiky učebnic z hlediska výskytu typů a obsahů vizuálních prostředků. Naopak nevýraznější rozdíly mezi učebnicemi byly zaznamenány u funkcí vizuálních prostředků. $\mathrm{V}$ závěru studie jsou uvedeny náměty na zlepšení učebnic formulované na základě zjištění z provedené analýzy.
\end{abstract}

Klíčová slova: vizuální prostředky, výuka reálií, učebnice němčiny, kategoriální systém, kurikulum

\section{1 Úvodem}

S nástupem komunikačního a interkulturního přístupu je možné v didaktice cizích jazyků zaznamenat nové vývojové tendence, v jejichž souvislosti jsou ve výuce reálií prosazovány nové cíle a obsahy interkulturně zaměřené výuky cizích jazyků (srov. Sturm, 1990, s. 11). Výuka reálií již není chápána pouze jako předávání faktografických poznatků o cílové zemi, nýbrž se týká všech aspektů společenského života cílové země a dovedností potřebných při interkulturní komunikaci (srov. Buttjes, 1991, s. 112). Vedle toho je $\mathrm{v}$ interkulturně zaměřené výuce cizích jazyků žádoucí rozvíjet také interkulturní komunikační kompetenci (dále IKK), jejímž „základem je jazyková vybavenost jednotlivce a respektování kulturních specifičností partnerů“ (Průcha, 2010, s. 46). Proto je třeba do učebnic cizích jazyků zahrnout exemplární témata reálií, která mohou k rozvíjení IKK přispět. Tyto nové vývojové tendence týkající se interkulturně zaměřené výuky cizích jazyků se projevují také v narůstání počtu vizuálních prostředků v učebnicích, s čímž souvisí potřeba hlouběji prozkoumat problematiku vizuálního

1 Vznik této studie byl podpořen Stipendijním fondem PdF MU (Podpora talentovaných prezenčních doktorandů) a projektem MUNI/A/0883/2011 Školní vzdělávání: podmínky, aktérí, kurikulum, procesy, výsledky. 
myšlení/porozumění ${ }^{2}$, jakožto chápání vizuálních informací, které může být kulturně podmíněno. V této souvislosti je však třeba upozornit na „bílá místa“ v oblasti pedagogické teorie, metodologie i praxe. Otázkou např. zůstává, jaké vlastnosti by měl mít kvalitní vizuální prostředek pro výuku reálií, aby bylo učení s ním co nejefektivnější. Proto bychom chtěli poukázat na to, jak důležitá je role vizuálních prostředků ${ }^{3}$ prezentujících učivo reálií v učebnicích cizích jazyků. Cílem prezentované studie je popsat charakteristiky vybraných učebnic němčiny z hlediska vizuálních prostředků pro výuku reálií s ohledem na vybrané teoretické a výzkumné poznatky v oblasti vizuálních prostředků v učebnicích a principy výuky reálií (tabulka 1). V centru naší pozornosti jsou přitom typy, obsahy a funkce vizuálních prostředků pro výuku reálií (viz tabulky 2-7).

\section{$2 \quad$ Konceptuální vymezení výuky reálií}

\subsection{Současné pojetí výuky reálií v didaktice cizích jazyků}

Současné pojetí výuky reálií chápeme jako kombinaci jejích tří základních př́stupů: kognitivního (faktografického), komunikačního a interkulturního (viz Pauldrach, 1992, s. 6). V kognitivním přístupu se ve výuce reálií jedná především o systematickou prezentaci faktů a poznatků o cílové zemi, které vycházejí z různých oborů (zeměpisu, dějepisu, politologie aj.). V komunikačním př́istupu je cílem rozvíjet komunikační kompetenci a předmětem výuky reálií jsou konverzační témata o každodenním životě obyvatel cílové kultury. Interkulturní přístup klade důraz na rozvoj komunikační a interkulturní kompetence, přičemž v centru pozornosti je vnímání cizí a vlastní kultury a strategií, které mají podpořit vzájemné porozumění při interkulturní komunikaci.

Domníváme se, že s výukou reálií souvisí rozvoj IKK, proto tuto problematiku též stručně nastíníme. IKK představuje složitý koncept, zahrnující kognitivní,

2 V německy psané odborné literatuře se setkáváme $\mathrm{v}$ podobném významu s pojmem Sehverstehen, některými autory označovaným jako pátá řečová dovednost, kterou je třeba ve výuce cizích jazyků rozvíjet (Schwerdtfeger, 1993).

3 Termín vizuální prostředky (německy visuelle Medien) jsme zvolili z toho důvodu, že je $\mathrm{v}$ diskursu didaktiky cizího (německého) jazyka etablovaný a jeví se jako vhodný pro kontext našeho výzkumu. Vizuální prostředky v učebnicích cizích jazyků (v našem případě němčiny) chápeme jako didaktické a komunikační prostředky, které zprostředkovávají učivo reálií názorným způsobem - především nonverbálně. Jedná se např. o fotografie, kresby, schémata, mapy apod. (viz Pešková, 2011). 
konativní/behaviorální a afektivní rovinu vymezenou prostřednictvím cílů ve formě znalostí, dovedností, postojů a hodnot, kterými by měli účastníci interkulturní komunikace disponovat (viz např. Byram, 1997). Příkladem modelu IKK použitého za účelem analýzy výuky angličtiny je model Zerzové (2011), který se skládá ze 4 cílových oblastí dělících se na obecné a specifické: znalosti Big-C culture, znalosti small-c culture, postoje a hodnoty a dovednosti/ chování . V naší práci vycházíme podobně z rozlišování dvou pojetí kultury, tedy konceptu Big-C culture, který pro kontext naší práce pojímáme jako učivo z oblasti historie, zeměpisu, umění, politiky apod. (srov. kognitivní pojetí reálií), a konceptu small-c culture, představující učivo o aspektech každodenního života, smýšlení a jednání lidí (blížící se komunikačnímu a částečně interkulturnímu pojetí reálií). Vzhledem $\mathrm{k}$ zaměření našeho výzkumu se tak zabýváme deskripcí vizuálních prostředků pro výuku reálií především s ohledem na utváření znalostí (viz kapitola 3 a 5).

\subsection{Pojetí výuky reálií ve stěžejních pedagogických dokumentech}

Jelikož se náš výzkum zaměřuje na problematiku výuky reálií na 2 . stupni Ž̌, věnujme pozornost kurikulárnímu dokumentu pro tento stupeň vzdělávání, jímž je Rámcový vzdělávací program pro základní vzdělávání (dále RVP ZV). V současnosti se na českých ZŠ vyučuje němčina převážně jako druhý cizí jazyk po angličtině jako prvním cizím jazyku, proto vycházíme z koncepce vzdělávacího oboru Další cizí jazyk (zahrnutého v Doplňujících vzdělávacích oborech).Zde je uvedeno, že žáci si mají osvojit pravidla komunikace v běžných každodenních situacích a naučit se jednoduchá sdělení. Mezi tematické okruhy zde patří domov, rodina, škola, volný čas a zájmová činnost, oblékání, nákupy, příroda a počasí, tradice a zvyky, svátky a důležité zeměpisné údaje (RVP ZV, 2007, s. 79). Jedná se tak spíše o reálie blízké komunikačnímu pojetí, v menší míre kognitivnímu pojetí. Na rozdíl od Společného evropského referenčního rámce pro jazyky (dále SERRJ), z kterého RVP ZV údajně vychází, zde však není učivo $v$ podobě tematických okruhů dále podrobněji zpracováno. Proto jsme se při tvorbě vlastního kategoriálního systému (viz kapitola 5) opírali především o témata uvedená v SERRJ (2002, s. 104-107)5.

\footnotetext{
K dalším modelům a vymezení IKK viz např. Rosinová (2008) a Kostková (2011).

5 Vycházíme z vymezení tzv. deklarativních znalostí, ke kterým patří znalosti okolního světa (faktografické znalosti týkající se především cílové země a obecné znalosti vztahující se k univerzálním tématům jako jsou časoprostorové vztahy), sociokulturní znalosti (znalosti společnosti a kultury cílové země vztahující se ke každodennímu životu, hodnotám, víře a postojům, řeči těla, společenským konvencím ad.) a interkulturální způsobilost (uvědomování si vlastní a cílové kultury, jejich podobností a odlišností).
} 


\section{Typy, obsahy a funkce vizuálních prostř̌edků pro výuku reálií}

Prezentovaný výzkum spadá do výzkumu kurikula, přičemž jsou zkoumány vizuální prostředky jakožto strukturní komponenty učebnice. Ve shodě s Průchou $(1998$, s. 25) se domníváme, že učebnice by měla být vytvářena nejen s ohledem na obsah vzdělávání, ale také na způsob prezentace obsahu. To, jak je obsah v učebnici prezentován, ovlivňuje efektivitu učení, což dokládá řada provedených výzkumů, které dále představujeme. $\mathrm{V}$ pozadí našeho výzkumu stojí přístup zvaný edukace založená na evidenci (evidencebased education), jenž zahrnuje shromažd'ování, zpracování, zprostředkování existujících výzkumných poznatků, jejich využívání v praxi a při „,kultivování“ odborné komunity (viz Mareš, 2009). V našem případě zjišt'ujeme, zda učebnice němčiny odpovídají aktuálním výzkumným poznatkům, které se týkají učení se $\mathrm{z}$ vizuálních prostředků v obecné rovině (v souvislosti s typy a funkcemi vizuálních prostředků), a vybraným principům cizojazyčné výuky v souvislosti s obsahy a funkcemi vizuálních prostředků pro výuku reálií.

\subsection{Typy vizuálních prostředků pro výuku reálií}

Řada výzkumných zjištění poukazuje na význam rozmanitosti vizuálních prostředků, pokud jde o zastoupení vizuálních prostředků různého typu. Každý typ vizuálního prostředku má totiž při procesu učení určité výhody či nevýhody (viz Mikk, 2000, s. 269-307). Od typu vizuálního prostředku se odvíjí také jeho funkce a způsob zpracování jeho obsahu žákem. Např. závěrem výzkumu Einsiedlera a Martschinkeové (1997) je doporučení, aby se v učebnicích objevovaly i logické (strukturované) vizuální prostředky, které podporují kognitivní zpracovávání prezentovaných informací a pomáhají žákům k pochopení vztahů a integraci osvojených znalostí.

Typy vizuálních prostředků lze posuzovat např. z hlediska toho, do jaké míry se podobají realitě, kterou zobrazují, jak jsou graficky ztvárněny, anebo jak mohou být vnímány („čteny“) recipientem. K základním typům, které se objevují v učebnicích cizích jazyků v souvislosti s reáliemi, řadíme: realistické (fotografie), analogické (kresby), logické (schémata, tabulky), symbolické (piktogramy), kartografické (mapy) a kombinované ${ }^{\text {(tabulka 2). }}$

6 Pro podrobnější vymezení typů vizuálních prostředků v obecné rovině odkazujeme na práci Weidenmanna (1991) a Ballstaedta (1997), v kontextu reálií v cizojazyčné výuce pak na práci Macaireové a Hosche (1999). 


\subsection{Obsahy vizuálních prostředků pro výuku reálií}

Pro vymezení obsahů vizuálních prostředků pro výuku reálií vycházíme z širších souvislostí obsahů výuky reálií, zejména jejich cílů a principů. Dle Tezí $A B C D$ ( $A B C D$-Thesen) z roku 1990 není primární úlohou reálií zprostředkování faktických informací a číselných údajů, ale senzibilizace a rozvoj schopností, strategií a dovedností při setkání s cizí kulturou (srov. Fischer, Frischherz, \& Noke, 2010, s. 1500). Významnou součástí výuky reálií je také zprostředkování znalostí k rozvoji uvědomění si vlastní a cizí kultury, mezikulturních podobností a odlišností (srov. Heyd, 1997, s. 34-74) a analýza stereotypů a odstraňování předsudků (Bausinger, 1988, s. 168). Učebnice cizích jazyků by tak měla zahrnovat určitá exemplární témata, která k takové výuce reálií přispívají. Lze vycházet z Byramova doporučeného minima témat (1993, s. 34-35), která se mají objevovat v učebnicích cizích jazyků a mají přispět k rozvíjení IKK. Patří mezi ně témata blízká zmíněnému konceptu Big-C Culture a small-c culture, protože zahrnují jak poznatky o cílové zemi, tak se zaměřují i na postoje a hodnoty spojené s určitou národní identitou.

Konkrétně v učebnicích němčiny jako cizího jazyka mají být pak dle konceptu $D-A-C H^{7}$ z roku 1993 zastoupeny všechny německy mluvící země (Německo, Rakousko, Švýcarsko). Rozšířenou variantou je koncept $D-A-C H-(L)$, který zahrnuje i Lucembursko a Lichtenštejnsko (L) viz Fischer et al. 2010, s. 1500).

\subsection{Funkce vizuálních prostředků pro výuku reálií}

V souladu s Paiviovou teorií duálního kódování ${ }^{8}$ by měly vizuální prostředky souviset $\mathrm{s}$ textem, aby bylo učení se $\mathrm{z}$ textu a vizuálního prostředku více efektivní (viz Mikk, 2000). V této souvislosti se dle výzkumných zjištění shrnutých Levinem, Anglinem a Carneym (1987) ukázaly jako nejméně vhodné vizuální prostředky $\mathrm{v}$ dekorativní funkci, která nemá na učení z textu žádný pozitivní účinek. Prokázalo se, že mírný účinek mají vizuální prostředky ve funkci reprezentující, středně velký účinek v organizující a interpretující a největší účinek ve funkci transformující (tabulka 5).

Koncept $D-A-C H$ navazuje na vydání Tezí $A B C D(1990)$ popisujících všeobecné a didaktickometodologické principy výuky reálií a možnosti společné spolupráce německy mluvících zemí v této oblasti (viz Hackl et al., 1998, s. 5-12).

8 Dle Paiviovy teorie duálního kódování existují dva paralelní systémy zpracování informací: verbální a vizuální. Oba systémy spolu souvisí a podílí se na zpracování textu (viz Paivio, 1986). 
Při učení se $\mathrm{z}$ vizuálních prostředků ve výuce němčiny jako cizího jazyka pak má být podle Biecheleové (1996, s. 753-755) naplněna aktivizující, konstrukční a instrukční, aplikační a kontrolní funkce vizuálních prostředků (tabulka 6). Vizuální prostředky v aplikační a kontrolní funkci realizují transfer znalostí, a jsou proto dle autorky ve výuce obzvláště důležité. Tuto skutečnost potvrzují Scherling a Schuckall (1992, s. 10-17), kteř́ také zdůrazňují význam vizuálních prostředků v aktivizující funkci, tedy na začátku probírání nového učiva.

V souvislosti se zprostředkováním informací by měly vizuální prostředky také zobrazovat sociální situace a jevy a připravovat tak žáky na sociální kontakt $\mathrm{v}$ cizojazyčném prostředí. Přitom je třeba upozornit na funkci komunikační, kterou považuje Pýchová (1990, s. 675) za nejdůležitější z tzv. sociálních funkcí, protože její potenciální vliv na osobnost žáka je obrovský. Spolu s dalšími sociálními funkcemi, jako je např. funkce orientační a regulační či propagační (tabulka 7), vizuální prostředky mj. napomáhají socializaci osobnosti žáka a jsou důležitým odrazem dění ve společnosti (Pýchová, 1990, s. 675). Tuto klasifikaci dále rozšiřujeme v kontextu výuky reálií o funkci faktografickou a interkulturní, korespondující se zmíněným pojetím reálií $\mathrm{v}$ kapitole 2.1 a obsahy výuky reálií $\mathrm{v}$ kapitole 3.2. Dále bychom chtěli upozornit na stereotypizující funkci, která se od ostatních funkcí vizuálních prostředků odlišuje svým „negativní nábojem“, protože může vést k prohlubování stereotypů o cizí kultuře. Přesto se v návaznosti na kapitolu 3.2 domníváme, že i stereotypy částečně patří do výuky reálií, zejména pokud jsou v hodinách analyzovány.

\section{Dosavadní stav poznání}

Ve výzkumu cizojazyčných učebnic se vizuálním prostředkům věnuje pozornost spíše okrajově, jak dále ilustrujeme na příkladech vybraných studií. V problematice prezentace obsahů učiva reálií vychází řada výzkumů z katalogů kritérií pro hodnocení cizojazyčných učebnic. Např. Chudak (2007) hodnotil na základě katalogu kritérií 5 učebnic němčiny pro dospělé. Ukázalo se, že z hlediska grafického zpracování byly učebnice vyhovující kromě jedné učebnice, učebnice obsahují bohatý materiál k výuce reálií (diferenciace témat a úloh se však od učebnice k učebnici liší) a autor hodnotí učebnice kladně i po stránce četnosti př́ležitostí k rozvoji IKK. 
$\mathrm{Z}$ důvodu změn obsahu kurikula je $\mathrm{v}$ současné době též žádoucí posuzovat cizojazyčné učebnice s ohledem na požadavky stěžejních dokumentů, jako je SERRJ a rámcové vzdělávací programy. Cools a Sercu (2006) zkoumali dvě učebnice němčiny pro mladistvé $\mathrm{z}$ hlediska toho, jak poskytují př́ležitosti k rozvíjení komunikační kompetence $v$ jednotlivých jejích úrovních stanovených v SERRJ (jednalo se pouze o úrovně A1-B1, přičemž předmětem analýzy byly typy textů, typy úloh, témata a strategie učení). Z výsledků kvantitativní analýzy vyplynulo, že obě učebnice jsou zaměřené na komunikační aktivity a podporují též učení pomocí vizuálních prostředků. Učebnice se však liší ve spektru témat a úkolů $\mathrm{k}$ výuce reálií.

Podobně Ježková (2008) metodou obsahové analýzy zkoumala soubor vybraných učebnic němčiny pro ZŠ z hlediska toho, jak splňuje požadavky týkající se rozvíjení sociolingvistické kompetence, vyplývající z RVP ZV a SERRJ. Cílem bylo mj. zjistit, jakým způsobem analyzovaný soubor učebnic prezentuje učivo reálií. V souvislosti s tím bylo také zjištováno, zda a jak se vizuální prostředky vztahují k učivu o reáliích německy mluvících (a dalších evropských) zemí. Výsledky naznačují, že obsah analyzovaných učebnic neodpovídá některým požadavkům na výuku reálií a $\mathrm{k}$ rozvíjení sociolingvistické kompetence přispívá pouze částečně.

\section{$5 \quad$ Metodologie vlastního výzkumu}

Cílem našeho výzkumu bylo zjistit, jaké typy, obsahy a funkce vizuálních prostředků pro výuku reálií se vyskytují v učebnicích němčiny a zda odpovídají vybraným teoretickým a výzkumným poznatkům (viz bod 1, 4 a 5 $\mathrm{v}$ tabulce 1) a principům výuky reálií (viz bod 2 a $3 \mathrm{v}$ tabulce 1 ), které jsme představili v kapitole 2 a 3 a nyní je shrnujeme v tabulce 1 .

Za tímto účelem jsme dle předem stanovených kritérií ${ }^{9}$ vybrali výzkumný vzorek učebnic, který tvoří 2 učebnice pocházející z českého nakladatelství: Deutsch mit Max 2 (Fišarová \& Zbranková, 2007), Macht mit! 2 (Jankásková et al., 2010) a 2 učebnice z německého nakladatelství: Planet 2 (Kopp, Bittner, \& Albert, 2005) a Genial 2 (Funk, et al., 2003). Předmětem výzkumu byly

\footnotetext{
Základní kritéria výběru byla: učebnice mají schvalovací doložku MŠMT ČR pro rok 2010/2011, jsou určeny pro výuku němčiny jako druhého cizího jazyka na 2. stupni ZŠ, mají k dispozici druhý díl (předpokládali jsme vyšší jazykovou úroveň němčiny a vyšší úroveň rozumových schopností žáků) a jsou vydány v různých českých nebo německých nakladatelstvích.
} 
vizuální prostředky pro výuku reálií, vztahující se $\mathrm{k}$ předem stanoveným tématům (tabulka 3). K posuzování vizuálních prostředků z vybraných hledisek jsme zvolili metodu kvantitativní analýzy pomocí navrženého kategoriálního systému (viz Pešková, 2010, 2011), který vychází převážně z teoretických a empirických prací představených v kapitole 2.

\section{Tabulka 1}

Shrnutí vybraných teoretických a výzkumných poznatků a principů výuky reálií

(1) V učebnicích by se měly objevovat rozmanité vizuální prostředky, aby vyhovovaly co nejvíce různým typům žáků a aktivizovaly různé myšlenkové operace žáků.

(2) Výuka reálií by neměla zahrnovat pouze zprostředkování faktických znalostí o cílové zemi (zeměpisných, dějepisných aj.), ale i zprostředkování znalostí o každodenním životě a znalostí k rozvoji uvědomění si vlastní a cizí kultury a k budování hodnot a postojů.

(3) V učebnicích němčiny jako cizího jazyka mají být formou vizuálních prostředků zastoupeny všechny německy mluvící země.

(4) Vizuální prostředky mají souviset s textem.

(5) Vizuální prostředky jsou při procesu učení se cizímu jazyku obzvláště důležité v aktivizující, aplikační a kontrolní funkci.

Za tímto účelem jsme dle předem stanovených kritériii ${ }^{10}$ vybrali výzkumný vzorek učebnic, který tvoří 2 učebnice pocházející z českého nakladatelství: Deutsch mit Max 2 (Fišarová \& Zbranková, 2007), Macht mit! 2 (Jankásková et al., 2010) a 2 učebnice z německého nakladatelství: Planet 2 (Kopp, Bittner, \& Albert, 2005) a Genial 2 (Funk, et al., 2003). Předmětem výzkumu byly vizuální prostředky pro výuku reálií, vztahující se $\mathrm{k}$ předem stanoveným tématům (tabulka 3 ). K posuzování vizuálních prostředků z vybraných hledisek jsme zvolili metodu kvantitativní analýzy pomocí navrženého kategoriálního systému (viz Pešková, 2010, 2011), který vychází převážně z teoretických a empirických prací představených v kapitole 2.

\subsection{Kategoriální systém}

Kategoriální systém se skládá ze tři částí: typů, obsahů a funkcí vizuálních prostředků pro výuku reálií. $\mathrm{V}$ případě typů jsme vycházeli především z klasifikace Ballstaedta (1997) a Weidenmanna (1991). Vymezení jednotlivých

10 Základní kritéria výběru byla: učebnice mají schvalovací doložku MŠMT ČR pro rok 2010/2011, jsou určeny pro výuku němčiny jako druhého cizího jazyka na 2. stupni ZŠ, mají k dispozici druhý díl (předpokládali jsme vyšší jazykovou úroveň němčiny a vyšší úroveň rozumových schopností žáků) a jsou vydány v různých českých nebo německých nakladatelstvích. 
kategorií bylo však kvůli vzájemnému překrývání nutné upřesnit a upravit. Proto jsou např. realistické vizuální prostředky pojaty jako fotografie, které rozlišujeme konkrétněji podle zobrazených objektů (tabulka 2).

\section{Tabulka 2}

\section{Typy vizuálních prostředků pro výuku reálií}

\begin{tabular}{|c|c|c|}
\hline \multicolumn{3}{|c|}{ Typy vizuálních prostředků pro výuku reálií } \\
\hline \multirow[t]{3}{*}{1.} & \multirow{3}{*}{$\begin{array}{l}\text { realistické } \\
\text { Jsou realitě věrné vizuální prostředky, ztvárněné } \\
\text { pomocí realistických barev a odstínů, z určitého } \\
\text { úhlu nebo perspektivy. Při jejich prohlížení } \\
\text { předpokládáme vysokou míru podobnosti se } \\
\text { skutečně existujícím objektem. }\end{array}$} & 1.1 fotografie \\
\hline & & $\begin{array}{l}1.2 \text { fotografie autentického } \\
\text { předmětu }\end{array}$ \\
\hline & & $\begin{array}{l}1.3 \text { reprodukce uměleckého } \\
\text { díla }\end{array}$ \\
\hline \multirow[t]{4}{*}{2.} & \multirow{4}{*}{$\begin{array}{l}\text { analogické } \\
\text { Jsou vizuální prostředky vytvořené různými } \\
\text { technikami, které recipientovi nabízí podobné } \\
\text { vizuální informace jako výřez reality, } \\
\text { jejž zprostředkovávají. Mají analogický, } \\
\text { popř. metaforický význam, který vychází z hlavních } \\
\text { rysů zobrazovaného. }\end{array}$} & 2.1 kresba \\
\hline & & $\begin{array}{l}2.2 \text { obrázkový příběh } \\
\text { a komiks }\end{array}$ \\
\hline & & 2.3 nákres \\
\hline & & \\
\hline \multirow[t]{2}{*}{3.} & logické & 3.1 schéma a diagram (graf) \\
\hline & $\begin{array}{l}\text { Nemají přímé zastoupení v realitě. Zobrazují } \\
\text { abstraktní struktury, vztahy, množství a postupy. } \\
\text { Jsou to systémy znaků, které získaly svůj význam } \\
\text { prostřednictvím konvencí. }\end{array}$ & 3.2 tabulka \\
\hline \multirow[t]{2}{*}{4.} & \multirow{2}{*}{$\begin{array}{l}\text { symbolické } \\
\text { Jsou stylizované vizuální prostředky vytvořené na } \\
\text { základě konvencí. Ve zjednodušené formě zastupují } \\
\text { známý koncept, mají reprezentující funkci. }\end{array}$} & 4.1 piktogram \\
\hline & & 4.2 znak a logo \\
\hline \multirow[t]{2}{*}{5.} & \multirow{2}{*}{$\begin{array}{l}\text { kartografické } \\
\text { Představují prostor ve zjednodušené a plošné } \\
\text { formě. Jedná se o zmenšené a do roviny upravené } \\
\text { dvojdimenzionální reprezentace zemské plochy. }\end{array}$} & 5.1 mapa \\
\hline & & 5.2 plán \\
\hline 6. & \multicolumn{2}{|l|}{$\begin{array}{l}\text { Skládají se z více typů vizuálních prostředků, } \\
\text { které dohromady tvoří jeden celek. }\end{array}$} \\
\hline
\end{tabular}

Obsahy vizuálních prostředků posuzujeme ze dvou hledisek: ze sociokulturního a z geografického. Při návrhu tematických okruhů ze sociokulturního hlediska jsme vycházeli z tematických okruhů vymezených v rámci deklarativních znalostí v SERRJ, tematických okruhů pro Další cizí jazyk v RVP ZV a z Byramova katalogu (1993). Jejich konkrétní příklady uvádíme v tabul- 
ce 3. V případě obsahů z geografického hlediska dle konceptu $D-A-C H-(L)$ rozlišujeme, ke které německy mluvící zemi se obsah vizuálního prostředku vztahuje (tabulka 4). Pro možnost výskytu několika německy mluvících zemí současně jsme vytvořili kategorii 2.5 více německy mluvících zemí a pro výskyt neutrálních (z geografického hlediska neidentifikovatelných) obsahů kategorii 2.6 neurčité.

Tabulka 3

Obsahy vizuálních prostředků pro výuku reálií ze sociokulturního hlediska

Obsahy vizuálních prostředků pro výuku reálií: 1. ze sociokulturního hlediska

1.1 národní geografie geografická poloha, sousedící státy, správní uspořádání, různá místa, města, regiony a jejich památky a turistické objekty, př́roda, obyvatelstvo (hustota zalidnění, počet obyvatel a další demografické údaje), hospodářství

1.2 národní historie historické události, osobnosti, objekty

1.3 stát a politika státní zrrízení, státní symboly, vláda a politický systém, politické strany, volby, školství, důležité instituce, německy mluvící země v EU

1.4 kultura a věda umění, známé osobnosti, masmédia, vynálezy

1.5 každodenní život bydlení, životní styl, činnosti a objekty všedního života, jídlo a pití, stolování, práce, škola, studium, volný čas, sport, služby, nakupování, zdravotní a sociální péče, doprava a cestování

1.6 sociální interakce společenské chování, společenské konvence, sociální kontakty a vztahy, verbální a nonverbální komunikace, tabu, výchova

1.7 národní a sociální národní a etnické menšiny, etnické a regionální odlišnosti, dialekt, identita hodnoty, postoje, náboženství, vlastní identita lidí, sociální skupiny, rodina, stereotypy a autostereotypy, tradice, svátky a zvyky

V návaznosti na teoretické a empirické práce zmíněné v kapitole 2.1, 3.2 a 3.3 posuzujeme funkce vizuálních prostředků pro výuku reálií ze tří hledisek: 1. ve vztahu $k$ textu, 2. ve vztahu $k$ procesu učení a 3. ve vztahu $k$ obsahu (tabulka 5, 6 a 7). Označení a vymezení některých podkategorií funkcí bylo upraveno na základě předvýzkumu a validizace kategoriálního systému. Vzhledem $\mathrm{k}$ tomu, že se mohou funkce $\mathrm{v}$ některých prŕpadech překrývat (v kategorii ve vztahu $k$ procesu učení a ve vztahu k obsahu), posuzovali jsme funkce podle kontextu vizuálního prostředku a zadání příslušné úlohy, pokud bylo $\mathrm{k}$ dispozici (vycházeli jsme přitom částečně také $\mathrm{z}$ metodické př́ručky učitele). 


\section{Tabulka 4}

\section{Obsahy vizuálních prostředků pro výuku reálií z geografického hlediska}

Obsahy vizuálních prostředků pro výuku reálií: 2 . z geografického hlediska

2.1 Německo

2.2 Rakousko

2.3 Švýcarsko

2.4 Lucembursko, Lichtenštejnsko

2.5 více německy mluvících zemí

2.6 neurčité
Obsah vizuálního prostředku se týká přednostně Německa

(např. vizuální prostředek zobrazuje památky z Berlína). Obsah vizuálního prostředku se týká přednostně Rakouska (např vizuální prostředek zobrazuje portrét W. A. Mozarta). Obsah vizuálního prostředku se týká přednostně Švýcarska (např. vizuální prostředek zobrazuje švýcarskou vlajku). Obsah vizuálního prostředku se týká přednostně Lucemburska nebo Lichtenštejnska (např. vizuální prostředek zobrazuje mapu Lucemburska).

Obsah vizuálního prostředku se týká dvou nebo více německy mluvících zemí (např. vizuální prostředek zobrazuje Alpy). Jedná se o neutrální téma. Není zřejmé, které německy mluvící země se obsah vizuálního prostředku týká (např. je na vizuálním prostředku zobrazen obchod s nápisy v němčině), nebo obsah vizuálního prostředku postihuje kromě německy mluvících zemí i jiné země.

\section{Tabulka 5}

\section{Funkce vizuálních prostředků pro výuku reálií ve vztahu k textu}

Funkce vizuálních prostředků pro výuku reálií: 1. ve vztahu k textu

1.1 dekorativní $\quad$ Vizuální prostředek přímo nesouvisí s textem. Je v učebnici zařazen z jiných důvodů, např. aby vyplnil prázdné místo, učinil text zajímavějším, odlehčil obtížný text výtvarným motivem.

1.2 reprezentující Vizuální prostředek reprezentuje obsah textu - tzn. zobrazuje osoby, objekty a činnosti zmíněné či popisované v textu. Slouží k zdůraznění hlavních narativních událostí textu, vztahuje se prímo k textu a konkretizuje jeho obsah.

1.3 organizující $\quad$ Vizuální prostředek organizuje obsah textu - poskytuje textu organizační rámec a ukazuje souvislosti; často zobrazuje nějaký postup, sled událostí, strukturu nebo výčet objektů.

1.4 interpretující Vizuální prostředek pomáhá pochopit text, vztahuje se k obtížnějším, méně známým konceptům, dětské zkušenosti se vymykajícím pojmům nebo pojmům abstraktním. Jedná se o předcházení vzniku mylných představ nebo přehodnocování dříve vzniklých miskoncepcí učiva.

1.5 transformující Má ovlivnit způsob, jímž si žák zpracovává a zapamatovává informace $\mathrm{z}$ textu. Vizuální prostředek často zdůrazňuje podstatné body z textu, přibližuje kontext nebo slouží jako mnemotechnická pomůcka k zapamatování obsahu textu nebo jednotlivých pojmů.

1.6 žádná Funkce ve vztahu k textu nelze v tomto případě určit, protože vizuální prostředek nedoprovází žádný souvislý text (nezohledňujeme nadpis nebo popisek). 


\section{Tabulka 6}

\section{Funkce vizuálních prostředků pro výuku reálií ve vztahu k procesu učení}

\begin{tabular}{|c|c|}
\hline \multicolumn{2}{|c|}{ Funkce vizuálních prostředků pro výuku reálií: 2 . ve vztahu k procesu učení } \\
\hline 2.1 aktivizující & $\begin{array}{l}\text { Vizuální prostředek aktivizuje myšlení a předchozí znalosti žáků, } \\
\text { motivuje je k učení a připravuje na osvojování nových znalostí. } \\
\text { Obvykle představuje nové téma nebo učivo, motivuje ke čtení či } \\
\text { poslechu textu či k rozvoji ústního/písemného projevu. }\end{array}$ \\
\hline 2.2 konstrukční & $\begin{array}{l}\text { Spočívá v podpoře (poskytování nových/doplňujících informací), popř. } \\
\text { řízení učebního procesu vizuálními prostředky (např. u obrázkových } \\
\text { příběhů). Žák získává nové poznatky, které spojuje s dosavadními } \\
\text { znalostmi. Úkolem žáka je „čtení“ (prohlížení si) vizuálního } \\
\text { prostředku. Jedná se tedy především o zprostředkování nových } \\
\text { informací, které si žák sám zpracovává. }\end{array}$ \\
\hline 2.3 aplikační & $\begin{array}{l}\text { Vizuální prostředek podporuje transfer a upevňování znalostí. Žák } \\
\text { s vizuálním prostředkem pracuje aktivně - tzn., nejedná se jen o pouhé } \\
\text { „čtení“ vizuálního prostředku, ale žák dostává i jiné úkoly jako popsat, } \\
\text { interpretovat, analyzovat, přiřazovat vizuální prostředky apod. }\end{array}$ \\
\hline 2.4 kontrolní & $\begin{array}{l}\text { Přináší ověření či zpětnou vazbu správnosti žákovy odpovědi. Může } \\
\text { sloužit i k testování nově osvojených znalostí žáků. }\end{array}$ \\
\hline
\end{tabular}

\section{Tabulka 7}

\section{Funkce vizuálních prostředků pro výuku reálií ve vztahu k obsahu}

\begin{tabular}{|c|c|}
\hline \multicolumn{2}{|c|}{ Funkce vizuálních prostředků pro výuku reálií: 3. ve vztahu k obsahu } \\
\hline $\begin{array}{l}3.1 \text { komunikační } \\
\text { a socializační }\end{array}$ & $\begin{array}{l}\text { Vizuální prostředek prezentuje situaci, kde probíhá nějaká forma } \\
\text { komunikace, prezentuje znaky verbální či neverbální komunikace. } \\
\text { Připravuje na sociální kontakt či pobyt v cizojazyčném prostředí: } \\
\text { zobrazuje sociální situace, osoby (a prostředí, v kterém žijí) nebo jevy, } \\
\text { s kterými se může žák v cílové zemi setkat. }\end{array}$ \\
\hline $\begin{array}{l}3.2 \text { orientační } \\
\text { a regulační }\end{array}$ & $\begin{array}{l}\text { Vizuální prostředek umožňuje orientaci v daném místě, prostředí či } \\
\text { systému, před něčím varuje, něco zakazuje nebo informuje o nějakém } \\
\text { stavu apod. }\end{array}$ \\
\hline 3.3 propagační & $\begin{array}{l}\text { Vizuální prostředek prezentuje symboly, reklamy, modely, prospekty, } \\
\text { kreslené nebo vyfotografované reálné předměty, které informují } \\
\text { o kulturních či volnočasových akcích, propagují nebo nabízí určité } \\
\text { produkty apod. }\end{array}$ \\
\hline 3.4 interkulturní & $\begin{array}{l}\text { Vizuální prostředek prezentuje interakci či vzájemný vztah dvou a více } \\
\text { kultur, umožňuje poznávat odlišnosti i podobnosti mezi kulturami. }\end{array}$ \\
\hline 3.5 stereotypizující & $\begin{array}{l}\text { Zobrazení situace, osob a jevů, které může přispět k vytváření či } \\
\text { prohlubování stereotypů, tzn. k vytváření zkreslených, zjednodušených } \\
\text { představ nebo názorů o dané kultuře/národu založených na } \\
\text { zevšeobecňování vlastností dané kultury/národa. }\end{array}$ \\
\hline
\end{tabular}




\begin{tabular}{ll}
\hline 3.6 faktografická & Vizuální prostředek prezentuje fakta o německy mluvících zemích \\
& získaná na základě skutečných údajů a dat. Zde rozlišujeme \\
& zprostředkování nominálních/numerických informací z reálií německy \\
& mluvících zemí (především pomocí logických vizuálních prostředků) \\
& a zprostředkování vizuálních kulturně a regionálně specifických \\
& informací, které jsou zobrazeny nonverbálně (jedná se o konkrétní \\
& kulturní produkty, reálné místo v dané zemi apod.). \\
\hline
\end{tabular}

\section{Výsledky výzkumu}

V této kapitole se věnujeme jednotlivým četnostem výskytu vizuálních prostředků pro výuku reálií z posuzovaných hledisek. Nejprve vždy uvádíme výsledky shrnující četnosti tř́d kategoriálního systému za celý výzkumný soubor, dále pak za jednotlivé učebnice.

\subsection{Výskyt typů vizuálních prostředků pro výuku reálií}

Co se týče celkového zastoupení kategorií typů vizuálních prostředků pro výuku reálií za všechny analyzované učebnice, dominují jednoznačně realistické vizuální prostředky (celkem cca 76 \%). Druhé nejvyšší zastoupení pak mají analogické vizuální prostředky (celkem cca 14\%). Nízké zastoupení mají kartografické vizuální prostředky a velmi zřídka se též vyskytují logické a kombinované vizuální prostředky. Menší rozdíly mezi učebnicemi jsou však patrné z hlediska zastoupení jednotlivých podkategorií typů (obrázek 1).

\subsection{Výskyt obsahů vizuálních prostředků pro výuku reálií}

Ve všech učebnicích se objevují podobná témata ze třídy 01.5 každodenní život (cca $41 \%$ ), jako je bydlení, nakupování, denní režim, volný čas, cestování ad., dále pak témata vztahující se k vlastní identitě mladistvých, zvykům a tradicím ze trrídy 01.7 národní a sociální identita (cca 20 \%). Nízké či nulové zastoupení mají ve všech učebnicích třídy 01.2 národní historie, 01.3 stát a politika a 01.4 kultura a věda. Z hlediska rovnoměrnosti zastoupení sledovaných obsahů jsou si podobné učebnice Deutsch mit Max a Planet, které mají obsahy ze sociokulturního hlediska v porovnání s ostatními učebnicemi rozmanitější (obrázek 2). 




IIII Deutsch mit Max

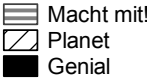

Obrázek 1. Výskyt typů vizuálních prostředků pro výuku reálií v jednotlivých učebnicích $(n=585)$. Pozn. Pro lepší čitelnost grafu jsme do grafu nezahrnuli T1.1 fotografie.

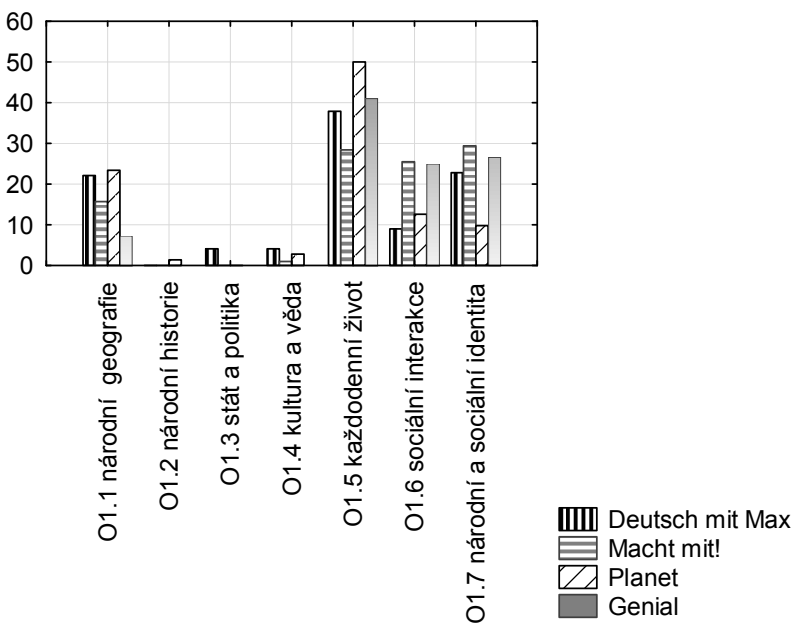

Obrázek 2. Výskyt obsahů vizuálních prostředků pro výuku reálií ze sociokulturního hlediska v jednotlivých učebnicích ( $\mathrm{n}$ = 585). 
Z geografického hlediska se vyskytují nejčastěji 02.6 neurčité obsahy ${ }^{11}$ (cca $58 \%$ ), které se explicitně nevztahují k žádné německy mluvící zemi, a obsahy zaměřené na Německo (cca $31 \%$ ). Společným rysem učebnic je také nulové zastoupení třídy 02.4 Lucembursko a Lichtenštejnsko. V rámci celého výzkumného souboru tak můžeme hovořit pouze o zohlednění principu $D-A-C H^{12}$, i když zastoupení těchto německy mluvících zemí je velmi nerovnoměrné (obrázek 3). Učebnice Genial má rozložení obsahů z geografického hlediska nejvíce rovnoměrné. Nejsilnější tendence zobrazovat obsahy vztahující se k Německu je patrná u německé učebnice Planet, což lze vysvětlit tím, že učebnice obsahuje řadu autentických vizuálních prostředků.
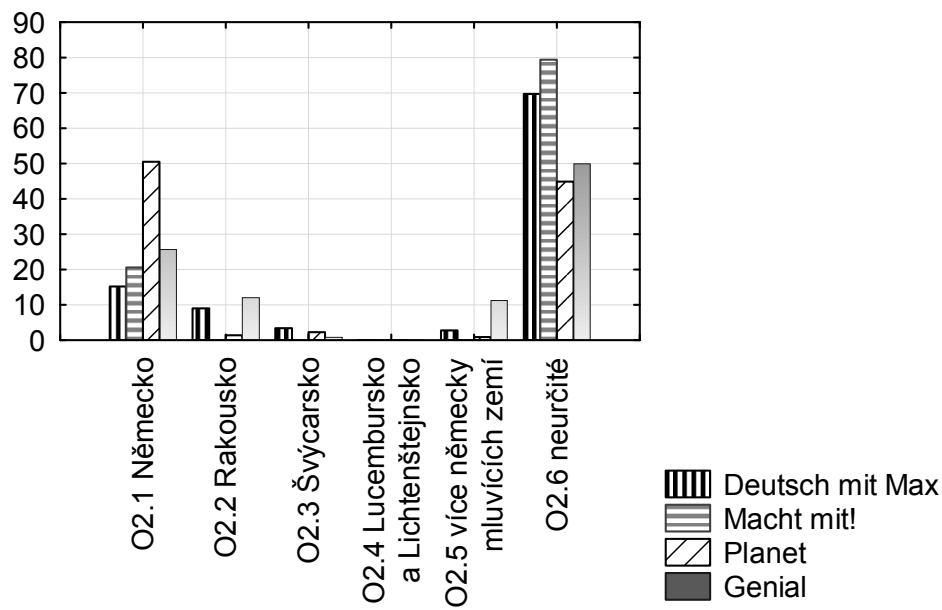

Obrázek 3. Výskyt obsahů vizuálních prostředků pro výuku reálií z geografického hlediska v jednotlivých učebnicích $(\mathrm{n}=585)$.

1 Tato tendence souvisí s vysokou četností výskytu třídy obsahů 01.5 každodenní život (tabulka 3), přičemž jsou prezentována témata univerzální, aplikovatelná pro všechny německy mluvící země.

12 Koncept $D-A-C H$ nezohledňuje jako jediná učebnice Macht mit!, v které jsou zastoupeny jen tř́dy 02.1 Německo a 02.6 neurčité. 


\subsection{Výskyt funkcí vizuálních prostředků pro výuku reálií}

Zastoupení funkcí ve vztahu $\mathrm{k}$ textu je ve všech učebnicích nerovnoměrné. Převažuje výskyt $F 1.2$ reprezentující funkce (celkem cca $61 \%$ ), druhé nejvyšší zastoupení má F1.6 žádná funkce ve vztahu k textu (cca 20 \%), která se však více objevuje v německých učebnicích (Planet a Genial). Velmi nízké či nulové zastoupení má funkce F1.3 organizující (cca 5 \%), F1.4 interpretující (cca $1 \%$ ) a F1.5 transformující $(0,2 \%)$.

Od ostatních učebnic se odlišuje počtem vizuálních prostředků v F1.1 dekorativní funkci učebnice Deutsch mit Max, kde se po F1.2 reprezentující funkci jedná o druhé nejvyšší zastoupení (cca 28 \%). Kromě učebnice Genial, v které jsou zastoupeny všechny funkce vizuálních prostředků (tř̌ebaže v zanedbatelné míře), je dále možné v každé učebnici identifikovat alespoň jednu funkci s nulovým výskytem (obrázek 4).

K nejfrekventovanějším funkcím ve vztahu k procesu učení za celý výzkumný soubor patří F2.2 konstrukční (cca 37 \%) a F2.3 aplikační funkce (35\%). 25 \% tvoří vizuální prostředky v F2.1 aktivizující funkci a naopak v silném kontrastu vůči ostatním funkcím je pak nízký výskyt F2.4 kontrolní funkce (cca $3 \%$ ).

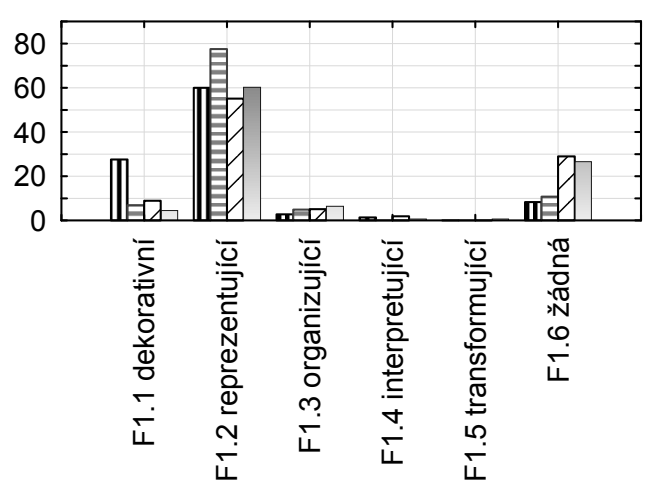

IIII Deutsch mit Max
$\square$ Macht mit!
$\square$ Planet
$\square$ Genial

Obrázek 4. Výskyt funkcí vizuálních prostředků pro výuku reálií ve vztahu $\mathrm{k}$ textu $\mathrm{v}$ jednotlivých učebnicích $(\mathrm{n}=585)$.

Zatímco v učebnicích Deutsch mit Max a Macht mit! jednoznačně převažuje výskyt F2.2 konstrukční funkce (přes 50 \%), v učebnici Planet dominuje 
s téměř 60\% zastoupením F2.3 aplikační funkce. Učebnice Deutsch mit Max a Macht mit! obsahují tedy spíše úlohy, v kterých se nevztahují k vizuálním prostředkům pro výuku reálíí žádná zadání, zatímco učebnice Planet obsahuje řadu úloh, kde mají být vizuální prostředky popisovány, interpretovány, přiřazovány apod. V učebnici Genial je kromě nižšího výskytu F2.4 kontrolní funkce zastoupení funkcí poměrně rovnoměrné (obrázek 5).

Nejčastější výskyt z funkcí ve vztahu k obsahu měla ve všech učebnicích funkce F3.1 komunikační a socializační (cca $54 \%$ ), přičemž lze pozorovat jistou souvislost s výskytem obsahů 01.5 každodenní život, 01.6 sociální interakce a 01.7 národní a sociální identita, a dále pak funkce F3.6 faktografická (cca $31 \%$ ), která souvisí především s prezentací obsahů 01.1 národní geografie a částečně 01.7 národní a sociální identita. Výskyt ostatních funkcí je v porovnání s těmito dvěma dominujícími funkcemi nízký (méně než 7 \%).

Lze konstatovat, že rozdíly mezi učebnicemi z hlediska výskytů funkcí ve vztahu k obsahu jsou menšího významu (obrázek 6). Nejrovnoměrnější rozložení funkcí má učebnice Planet. Nízký výskyt má F3.5 stereotypizující funkce, kterou jsme identifikovali pouze v učebnici Genial (cca 7 \%) a v zanedbatelné míře v učebnici Planet (cca $1 \%$ ), což patrně souvisí s tím, že se $\mathrm{v}$ německých učebnicích projevuje silnější tendence výskytu obsahů zaměřených na reálie Německa (viz kapitola 6.2).
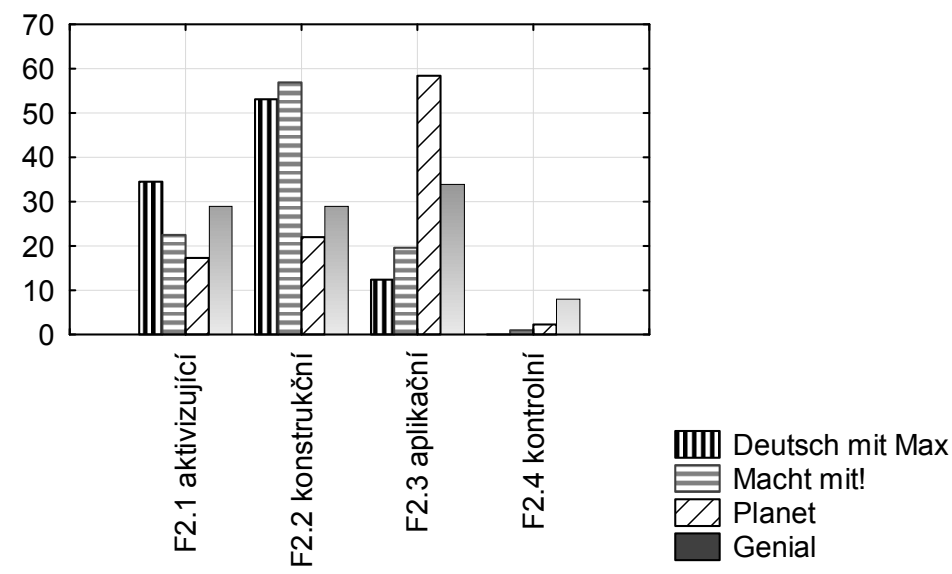

Obrázek 5. Výskyt funkcí vizuálních prostředků pro výuku reálií ve vztahu k procesu učení $v$ jednotlivých učebnicích $(n=585)$. 


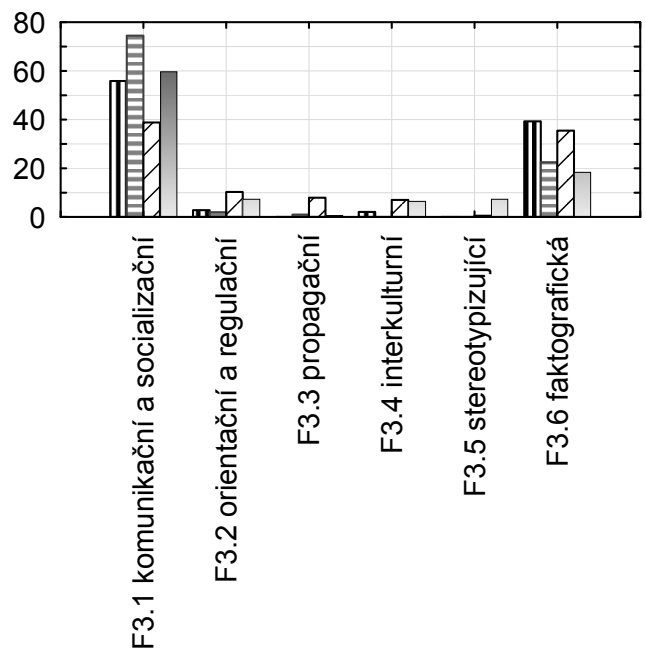

IIII Deutsch mit Max
Macht mit!
$\square \triangle$ Planet
$\square$ Genial

Obrázek 6. Výskyt funkcí vizuálních prostředků pro výuku reálií ve vztahu k obsahu v jednotlivých učebnicích $(n=585)$.

\section{Závěry a diskuse}

Výsledky analýzy korespondují s některými zjištěními výzkumů jiných autorů, např. Chudaka (2007) nebo Cools a Sercu (2006), dle kterých se učebnice němčiny liší především svým spektrem témat a úkolů k výuce reálií. V našem případě se jednalo zejména o rozdíly $\mathrm{v}$ prezentaci témat $\mathrm{v}$ geografickém kontextu a ve funkcích vizuálních prostředků ve vztahu k procesu učení (souvisejících se zadáním úloh v učebnici a pokyny v metodické př́íručce).

Výsledky analýzy poukázaly také na některé společné tendence učebnic. Jednou $\mathrm{z}$ nich je bezesporu převaha realistických vizuálních prostředků (fotografií), což patrně souvisí s prosazováním didaktického principu autentičnosti a motivační stránky výukových materiálů (viz např. Fritz \& Faistauer, 2008), jelikož prostřednictvím fotografií vidí žáci obraz reality, se kterou se mohou v budoucnu setkat. Tato skutečnost má však za následek to, že žáci mají měně příležitostí k aktivizaci různých myšlenkových operací (viz bod $1 \mathrm{v}$ tabulce 1 ). Další společná tendence učebnic je patrná ve výskytu témat z každodenního života a sociálně zaměřených témat (témat týkajících 
se small-c culture). Celý výzkumný soubor též charakterizuje dominantní výskyt vizuálních prostředků v reprezentující funkci, což patrně souvisí $\mathrm{s}$ cílovou jazykovou úrovní žáků. Vizuální prostředky v reprezentující funkci pomáhají odhadnout obsah textu a podporují porozumění informacím, které jsou v něm obsaženy. Proto lze hypotetizovat, že vizuální prostředky v této funkci budou přínosné zejména pro žáky s nižší jazykovou úrovní.

Zároveň se ukázaly některé rozdíly mezi českými a německými učebnicemi, zejména ve výskytu obsahů z geografického hlediska a ve výskytu funkcí. Rozdíly v obsahovém zaměření učebnic lze interpretovat tím, že v českých učebnicích je učivo zpracováno dle požadavků RVP ZV (jak se uvádí v příslušných metodických př́ručkách učebnic), což může souviset se silnější tendencí výskytu neurčitých obsahů (nespecifických každodenních témat). Další rozdíly si vysvětlujeme různou cílovou jazykovou úrovní českých a německých učebnic (Deutsch mit Max a Macht mit! směřují k dosažení úrovně A1, Planet a Genial k A2). Německé učebnice jsou proto vzhledem $\mathrm{k}$ jejich cílové jazykové úrovni $\mathrm{z}$ hlediska úloh s vizuálními prostředky náročnější, což se odráží ve vyšším výskytu aplikační funkce. Jelikož se ze stejného důvodu nachází v německých učebnicích i více složitějších textů, očekávali bychom v nich též vyšší výskyt funkcí podporujících učení z textu (organizující, interpretující a transformující). Zjištění však bylo překvapivé, protože zde naopak převažovaly vizuální prostředky v žádné funkci ve vztahu $\mathrm{k}$ textu ${ }^{13}$. U každé učebnice jsme identifikovali některé silné a slabé stránky, $\mathrm{v}$ čemž chápeme smysl této analýzy. Vyvstaly některé náměty na zlepšení, především v souvislosti s vybranými poznatky (tabulka 1), které nebyly $\mathrm{v}$ učebnicích zohledněny či byly zohledněny jen částečně:

1. I když se realistické vizuální prostředky jeví vzhledem ke svému četnému výskytu v učebnicích jako vhodné pro výuku reálií, je třeba zahrnout do učebnic rozmanitější vizuální prostředky, aby vyhovovaly co nejvíce různým typům žáků a aktivizovaly různé myšlenkové operace u žáků.

2. Koncept $D-A-C H$ je zohledňován (kromě jedné učebnice), ovšem s dominantním zastoupením vizuálních prostředků zobrazujících reálie z Německa. Země Lichtenštejnsko a Lucembursko zahrnuté v konceptu $D-A-C H-(L)$ nejsou však explicitně prezentovány vůbec.

13 Výsledky analýz učebnic př́rodovědných oborů také poukazují na slabou spojitost mezi textem a vizuálními prostředky (viz např. Perales \& Jimenéz, 2002), což je z našeho pohledu překvapivé zjištění vzhledem $\mathrm{k}$ tomu, že učebnice př́rodovědných předmětů obvykle obsahují výkladové texty, u nichž je vizuální podpora k objasnění výkladu obzvláště třeba. 
3. Z funkcí ve vztahu k procesu učení má nejvyšší zastoupení konstrukční funkce, až na druhém místě aplikační funkce, která je zejména důležitá pro transfer a upevňování znalostí.

4. Relativně vysoký počet vizuálních prostředků nedoprovází žádný souvislý text a nezobrazuje přímo obsah textu. Tuto skutečnost považujeme za alarmující vzhledem $\mathrm{k}$ tomu, že vizuální prostředky bez přímé vazby na text nepodporují učení z textu.

Ukázalo se, že vybraným principům výuky reálií (tabulka 1) vyhovují z pohledu celého výzkumného souboru pouze obsahy vizuálních prostředků ze sociokulturního hlediska. Nesoulad je patrný s poznatkem týkajícím se funkcí ve vztahu $\mathrm{k}$ textu (bod $4 \mathrm{v}$ tabulce 1) a z ostatních posuzovaných hledisek se jedná o soulad částečný. Domníváme se, že ke zkvalitnění učebnic z hlediska vizuálních prostředků pro výuku reálií by přispělo zohlednění výše uvedených zjištění. Jsme si však vědomi toho, že náš výzkum poodkryl jen část problematiky výuky reálií pomocí vizuálních prostředků v učebnicích a je třeba ji dále zkoumat. Jelikož byl prezentovaný výzkum koncipován především jako deskriptivní šetření v rovině zprostředkovávaných znalostí, nabízí se např. otázka, jak vizuální prostředky pro výuku reálií vnímají sami žáci a jak jsou pomocí vizuálních prostředků rozvíjeny ostatní roviny IKK, tedy konativní/behaviorální a afektivní. Věříme, že náš kategoriální systém bude po menších úpravách „odrazovým můstkem“ i pro výzkumy učebnic jiných cizích jazyků.

\section{Literatura}

ABCD-Thesen zur Rolle der Landeskunde im Deutschunterricht. (1990). Fremdsprache Deutsch, $3,60-61$.

Ballstaedt, S. P. (1997). Wissensvermittlung. Die Gestaltung von Lernmaterial. Weinheim: Beltz Psychologie Verlags Union.

Bausinger, H. (1988). Stereotypie und Wirklichkeit. Jahrbuch Deutsch als Fremdsprache, 14, 157-190.

Biechele, B. (1996). Bilder als Kommunikate und Lernmedien im Fremdsprachenunterricht/ DaF. Informationen Deutsch als Fremdsprache (Info DaF), 23(6), 746-757.

Buttjes, D. (1991). Landeskunde-Didaktik und landeskundliches Curriculum. In K. J. Bausch (Ed.), Handbuch Fremdsprachenunterricht (s. 112-119). Tübingen: Francke.

Byram, M. (1993). Germany. Its representation in textbooks for teaching German in Great Britain. Frankfurt am Main: Diesterweg

Byram, M. (1997). Teaching and assessing intercultural communicative competence. Clevedon: Multilingual Matters Ltd. 
Cools, D., \& Sercu, L. (2006). Die Beurteilung von Lehrwerken an Hand des Gemeinsamen Europäischen Referenzrahmens für Sprachen: Eine empirische Untersuchung von zwei kürzlich erschienenen Lehrwerken für Deutsch als Fremdsprache. Zeitschrift für Interkulturellen Fremdsprachenunterricht, 11(3), 1-17.

Einsiedler, W., \& Martschinke, S. (1997). Elaboriertheit und Strukturiertheit in Schulbuchillustrationen des Grundschulsachunterrichts. Nürnberg: Institut für Grundschulforschung der Universität Erlangen - Nürnberg.

Fišarová, O., \& Zbranková, M. (2007). Němčina A1. Deutsch mit Max - díl 2. Učebnice pro základní školy a víceletá gymnázia. Plzeň: Fraus.

Fischer, R., Frischherz, B., \& Noke, K. (2010). DACH-Landeskunde. In H. J. Krumm, Ch. Fandrych, B. Hufeisen, \& C. Riemer (Eds.), Deutsch als Fremd- und Zweitsprache: Ein Internationales Handbuch (s. 1499-1510). Berlin, New York: Gruyter.

Fritz, T., \& Faistauer, R. (2008). Prinzipien eines Sprachunterrichts In E. Bogenreiter-Feigl (Ed.), ¿Paradigmenwechsel? Sprachenlernen im 21. Jahrhundert: Szenarios - Anforderungen Profile - Ausbildung (s. 125-133). Wien: Verband Österreichischer Volkshochschulen.

Funk, H. et al. (2003). Geni@l - Němčina jako druhý cizí jazyk. Kursbuch A2. Berlin, München: Langenscheidt.

Hackl, W., Langer, M., \& Simon-Pelanda, H. (1998). Landeskundliches Lernen. Fremdsprache Deutsch, 18, 65-12.

Heyd, G. (1997). Aufbauwissen für den Fremdsprachenunterricht (DaF). Tübingen: Francke Verlag.

Chudak, S. (2007). Lernerautonomie fördernde Inhalte in ausgewählten Lehrwerken DaF für Erwachsene. Überlegungen zur Gestaltung und zur Evaluation von Lehr- und Lernmaterialien. Possener Beiträge zur Germanistik. Frankfurt am Main: Peter Lang.

Jankásková, M. et al. (2010). Macht mit!: učebnice němčiny pro základní školy a víceletá gymnázia, druhý cizí jazyk. 2. díl. Praha: Polyglot.

Ježková, V. (2008). Výzkum souboru učebnic němčiny pro základní školy. In P. Knecht, \& T. Janík, et al., Učebnice z pohledu pedagogického výzkumu (s. 137-145). Brno: Paido.

Kopp, G., Büttner, S., \& Albert, J. (2005). Planet 2: Deutsch für Jugendliche. Kursbuch. Ismaning: Hueber Verlag.

Kostková, K. (2011). Hodnocení (rozvoje) interkulturní komunikační kompetence. In T. Janík, P. Knecht, \& S. Šebestová (Eds.), Smíšený design v pedagogickém výzkumu: Sborník př́spěvků z 19. výroční konference České asociace pedagogického výzkumu (s. 168-174). Brno: Masarykova univerzita.

Levin, J. R., Anglin, G. R., \& Carney, R. N. (1987). On empirical validating functions of picture in prose. In D. M. Willows, \& H. A. Houghton (Eds.), The psychology of illustration (s. 51-85). New York: Springer Verlag.

Macaire, D., \& Hosch, W. (1996). Bilder in der Landeskunde. Berlin: Langenscheidt.

Mareš, J. (2009). Edukace založená na důkazech: inspirace pro pedagogický výzkum i školní praxi. Pedagogika, 59(3), 232-258.

Mikk, J. (2000). Textbook. Research and writing. Frankfurt: Peter Lang GmbH.

Paivio, A. (1986). Mental representations. A dual coding approach. Oxford, UK: Oxford University Press.

Pauldrach, A. (1992). Eine unendliche Geschichte. Anmerkungen zur Situation der Landeskunde in den 90er Jahren. Fremdsprache Deutsch, 6, 6-15. 
Perales, F. J., \& Jiménez, J. D. (2002). Las ilustraciones en la enseñanza - aprendizaje de las ciencias. Análisis de libros de texto. Enseñanza de las Ciencias, 20(3), 369-386.

Pešková, K. (2010). Návrh diagnostického nástroje pro hodnocení vizuálních prostředků v učebnicích německého jazyka pro výuku reálií. In T. Janík, P. Knecht, \& P. Najvar, et al., Nástroje pro monitoring a evaluaci kvality výuky a kurikula (s. 192-201). Brno: Paido.

Pešková, K. (2011). Metodologické aspekty analýzy učebnic německého jazyka z hlediska vizuálních prostředků pro výuku reálií. In T. Janík, P. Najvar, \& M. Kubiatko, et al., Kvalita kurikula a výuky: výzkumné př́stupy a nástroje (s. 97-112). Brno: Masarykova univerzita.

Průcha, J. (1998). Učebnice: teorie a analýzy edukačního média: př́ručka pro studenty, učitele, autory učebnic a výzkumné pracovníky. Brno: Paido.

Průcha, J. (2010). Interkulturní komunikace. Praha: Grada.

Pýchová, I. (1990). K funkci vizuálií v rozvoji osobnosti žáka. Pedagogika, 40(6), 669-684.

Rosinová, M. (2008). Interkulturní výchova a vzdělávání v cizojazyčném vyučování (disertační práce). Praha: Univerzita Karlova v Praze.

Rámcový vzdělávací program pro základní vzdělávání. (2007). Praha: VÚP v Praze.

Společný evropský referenční rámec pro jazyky. (2002). Olomouc: Univerzita Palackého v Olomouci.

Scherling, T., \& Schuckall, H. F. (1992). Mit Bildern lernen. Berlin, München: Langenscheidt.

Schwerdtfeger, I. C. (1993). Sehen und Verstehen. Arbeit mit Filmen im Unterricht als Fremdsprache. Berlin, München: Langenscheidt.

Sturm, D. (1990). Zur Visualisierung von Lehrwerken für Deutsch als Fremdsprache. Historische und kulturkontrastive Aspekte (Dissertation). Kassel: Universität Kassel.

Weidenmann, B. (1991). Lernen mit Bildmedien. Psychologische und didaktische Grundlagen. Weinheim (u.a.): Beltz.

Zerzová, J. (2012). Interkulturní komunikační kompetence a její rozvíjení v hodinách anglického jazyka na 2. stupni Ž̌. Brno: Masarykova univerzita.

\title{
Autorka
}

Mgr. Karolína Pešková, Masarykova univerzita, Pedagogická fakulta, Katedra německého jazyka a literatury, Poříćí 9, 60300 Brno, e-mail: peskova@ped.muni.cz

\section{Visuals for teaching culture: an analysis of German as a second language textbooks}

\begin{abstract}
The study presents results of a quantitative analysis of visuals for teaching culture in German language textbooks. The research sample consisted of four textbooks for teaching German as a second foreign language at lower secondary schools. The results showed some tendencies which the textbooks have in common,
\end{abstract}


particularly concerning types and contents of the visuals. On the contrary, the main differences between the textbooks were identified in functions of the visuals. Based on the findings of the analysis some tips on improving the textbooks are suggested at the end of the study.

Keywords: visuals, German language textbooks, system of categories, curriculum, teaching culture

Zerzová, J. (2012). Interkulturní komunikační kompetence a její rozvíjení v hodinách anglického jazyka na 2. stupni ZŠ. Brno: Masarykova univerzita.

Publikace je věnována problematice výuky reálií a rozvíjení interkulturní komunikační kompetence v rámci výuky anglického jazyka na 2 . stupni ZŠ a představuje první pokus o uchopení této složité problematiky v kontextu pedagogického výzkumu v České republice. V knize jsou představena dvě výzkumná šetření (výzkum realizovaného kurikula a výzkum učitelova pojetí kultury a cílů výuky reálií a interkulturní komunikační kompetence). Výsledky výzkumu mimo jiné naznačují, že hlavním aspektem, který snižuje kvalitu výuky reálií a interkulturní komunikační kompetence je jednostranné zaměření na znalosti žáků. Zdá se, že dovednosti potřebné v kontextu interkulturních interakcí nejsou ve výuce rozvíjeny a s postoji žáků k cizím kulturám a interkulturním interakcím není systematicky pracováno. Publikace rovněž nabízí perspektivy dalšího výzkumu v této oblasti a současně otvírá řadu metodologických otázek - souvisejících jak s již realizovaným výzkumem, tak s potenciálními výzkumy v budoucnosti - které jsou nabídnuty čtenářủm k další diskusi. 